\title{
THE COMMON AGRICULTURAL POLICY THROUGH REFORMS TOWARD EUROPE 2020
}

\author{
Goran Puzić1, Aleksandar Klevernić ${ }^{2}$, Zoran Pavlović ${ }^{3}$
}

\begin{abstract}
Summary
At the start of the European integration process, although the focus was on the European Coal and Steel Community, the specific treatment of agriculture was well-known information. Often, the agricultural sector was the decisive factor in the dynamics and intensity of the integration process as a whole. That role of agriculture is maintained, but in a lot of changed conditions and with different strategy that includes the development of new targets and mechanisms. The Common Agricultural Policy (CAP) has more than 50 years one of the most expensive and the most intriguing of all EU policies. It, beside regional policy, is a key policy and many aspects of other policies of EU are diffracted on this topic. The aim of this research is the intersection of the previous reforms of the CAP until the Agenda "Europe 2020" and influence on the agricultural income and direct payments on selected countries - Bulgaria, Romania and Croatia. During research, we have used the methods of economic and political analysis and comparative-historical and current structural and dynamic context of the EU.
\end{abstract}

Key words: Common Agricultural Policy, EU, CAP reforms, Europe 2020.

JEL: $Q 18$.

\section{Introduction}

The CAP is one of the most controversial and the oldest policies of EU. For this claim there are several reasons: Firstly, agriculture has always been an essential factor in economics, social and cultural life of the people. Secondly, farmers from Europe had, and still have, a huge political influence in all parliamentary regimes within democratic systems of Europe. As a third, and maybe the most important, after the Second World War, one of the main

1 Goran Puzić, Ph.D., Associate Professor, Megatrend University, Faculty of Law, Public Administration and Security, Bulevar umetnosti 29, 11070 Novi Beograd, Serbia, Phone: +381 65 20819 77, E-mail: gpuzic@megatrend.edu.rs

2 Aleksandar Klevernić, M.Sc., Vulcascot Ltd., Vladimira Nazora Street BB, 22400 Ruma, Serbia, Phone: +38165 25277 29, E-mail: a.klevernic@vulcascot.rs

3 Zoran Pavlović, Ph.D., Associate Professor, University Business Academy, Faculty of Law, Geri Karolja Street 1, 21000 Novi Sad, Serbia, Phone: +381 658677 949, E-mail: zoran.pav@hotmail.com

EP 2014 (61) 3 (759-770) 
strategic objectives of the European countries was to achieve and guarantee the safety of food supply for the entire population as soon as possible. Thus, the dynamics of the CAP has significantly influenced on dynamics of the European Communities.

\section{The establishment and development of the CAP}

The beginning of the CAP is linked to the 1950s in Western Europe, whose societies was drastically damaged by years of war, whose agriculture was practically "crippled" and where it was not possible to guarantee enough food for all (Zobbe, 2001). The original aim of the CAP was to encourage the production of food so that consumers had a stable supply, and to provide stable agricultural sector for former European Community (European Commission, 2011). Prior to establishment of the CAP, the first time since 1870s and the Franco-Prussian war, all countries are turning to protectionism as a common denominator of national policy at that time, including the traditional British (Miščević and Dragojlović, 2010). In accordance with that time, the agriculture on the level of national countries has largely been subsidized by the state, as the majority of the population in pre-industrial period was engaged in this activity $^{4}$. Subsidies were related to the addition to the market price, import quotas on foreign goods, direct payments to the farmers (which is still the most attractive item of the CAP) support of research and production of new species (which is the characteristic of wealthier countries in Europe). There are different opinions regarding the origin of the CAP. One of the most interesting positions is related to the alleged deal between France and Germany. Namely, during the 50's, France in exchange for opening their market for industrial goods from Germany, asked for a counter service in the form of the opening of the German market for agricultural products from France (Prokopijević, 2009). This attitude is the product of hypothetical reasoning which is not completely followed with the facts and appropriate documents by the authors who have advocate this position (Hiks, 2007). On the other hand, the undeniable fact was that the price-standard for agricultural market protection was adopted from Germany, which was higher than the French one. From this point of view, France has achieved benefit, since the burden of its budget was transferred to the central budget of EEC which was mainly funded by Germany and Netherland. All Western European countries (except the United Kingdom) had a significantly inefficient agricultural sector regarding to USA, as there was a strong pressure of agricultural products from the States to European agricultural market. Unification of protectionist policies within agriculture, created a sanctuary for all Western European agriculture, and at the same time there was also an initial step towards to creation of the CAP. Especially importance for establishing this policy we can find in Treaty of Rome which gives to agriculture the major role and in Summit in Stresa at 1958 which included the common market for agricultural products, the priority of Community domestic production over imports and centralized finance of the CAP 5 .

4 On this way, the state has contributed to a significant price increase of foreign goods on domestic market, and thus accounted for much less competitive according to the others, and on the other hand favored domestic producers and narrowing the area for the customers in wider choice and better range of the goods.

5 Implies the transfer of funding from national level to the Comunity. 
Chronological development review of CAP can be summarized as follows:

Period from the beginning till the sixties in the $20^{\text {th }}$ century.

- Initial establishment of the CAP

Period $1960-1980$.

- $\quad$ The period of overall productivity and high investments level in CAP (in 1984. almost $70 \%$ of the EEC budget was related to the CAP).

Period $1980-1990$.

- Dealing with market surpluses and the first attempts to decrease CAP participation within EEC budget.

Period from Maastricht until 2004.

- Implementation of direct payment policy and the beginning of the establishment of rural development policy.

Period from 2005. $\rightarrow$

- Implementation of the single payment scheme and the payments separation from the production of certain crops (Miščević and Dragojlović, 2010).

\section{The CAP reforms}

This policy has practically come to life in 1962 when the country members of the former EEC started to apply $\mathrm{CAP}^{6}$. In the same year, they formed the European Agricultural Guarantee Fund (EAGF), who has supported since 1964 guarantee prices on the market from one side, and from the other has supported the structural reforms of the national agricultural policy. The result of this policy was the creating of market surplus and the higher price level on the EEC market relative to the world agricultural scene. This development has contributed to the first reform of the CAP which is perhaps the most far-reaching one. It is the Mansholt plan (Sicco Mansholt, former Commissioner of Agriculture) which are predicted the reduction of arable land for about 5 million hectares, revision of price policy, increasing the farm size and their production specialization (Prokopijević, 2009). This reform was not initially accepted because it was considered as a too radical, and because it would lead to restructuring of agriculture continuing with the retrain of workers, retirements and urbanization of a large part of the population ${ }^{7}$. The plan was partially accepted. The next reform was carried out in 1988 as a MacSherry reform ${ }^{8}$ when they introduced two institutes of fundamental importance: „leaving aside“" and direct payments. Leaving aside means the un-treatment of a certain

6 France, Western Germany, Benelux and Italy.

7 The fact is that during this period, a huge number of the EU population was oriented to the agricuture. Accordingly, we should not forget that the CAP has enormously contributed to the farmer ,yes“ for integration process.

8 Ray MacSherry, former European Commissioner of Agriculture.

EP 2014 (61) 3 (759-770) 
part of the land in order to reduce the production and to avoid redundancies. This institute was soon abandoned, given that there has been an increase in imports and the potential risk to environment (excessive use of chemicals). The direct payments were introduced as a replacement. That institute (direct payments) has become the main form of agricultural financing, because they enabled the successful functioning of economic paradox: low prices of agricultural products, in order to be closer to global price level, together with unchanged production quantities. The logical economic effect on the decline in price of the product will be decreasing of produced quantities. However, the CAP is through direct payments providing that the outcome of the logic "going to the mill" of the producers, via covering the income that is lost due the lower prices (Pezaros, 1999). This type of compensation initially paid per hectare, and later the practice was changed (Knizkel et al, 2009). The point of all changes during the 80's was to reduce subsidies on production and the production thereby drastically reduced, in order to avoid an increase in imports. In this way an attempt was to prevent the creation of surplus of agricultural products (Prokopijević, 2009).

With reform "Agenda 2000" from 1999 EU introduced the European model of agriculture based on the following elements:

- Competitive agricultural sector;

- Production focused on quality products and environmental protection;

- Diversification of agriculture;

- Active rural community;

- Reasonable and unique agricultural policy based on responsibility separation between EU and country members;

- Clear benefits to society of the money spending on agriculture (Miščević and Dragojlović, 2010).

Specific treatment of agriculture is logical if we considered that the food is essential factor for human survival. Therefore, protective measures are necessary (Marković and Marković, 2014). Within the CAP was introduced the pillar structure of agriculture: market support through guaranteed prices system and rural development. Over the time, the guaranteed prices of certain products have decreased, but the compensations to producers were still withheld. The EU also introduced the institute of ,cross-conditionality "which is related to the environment protection and food quality as a condition for right on a direct payment consummation. Rural development policy has entailed strengthening of agricultural sector, environmental protection and modernization of rural areas. One of the recent reforms of this policy was introduced in the year 2003 and this reform was the base for the further development of agricultural policy. Single payment scheme was the part of the mentioned reform. Namely, in order for manufactures to be able to receive mentioned payment benefits, it was necessary to fulfill following conditions: that in the reference period they have already used grant subsidies, to meet the standards of the environment, public health and health of domestic animals and to provide the protection of the land in arable state. All of these conditions are related to the 2 required groups: statutory management requirements and 
keeping the land in good condition in accordance with clean environment. Although these goals were tied to draw closer market reality to the farmers in order to prepare them for the future competition, however, the CAP has remained a big dose of protectionism (export subsidies, leaving aside, emergency supplies) and market state management. The aim of the previous reforms was to reduce the participation of the CAP within EU budget ${ }^{9}$, to increase the competitiveness of the agriculture at the global market, and to continuously improve the food quality and agricultural production, but not on the cost of environmental damaging and human health.

Before of the inclusion of a new member states at $2004^{10}$. EU attempted another reform which was initiated by EU15 ${ }^{11}$. The main goal of this reform, which was initiated by Commissioner of Agriculture - Franz Fischler, was to limit the outflow from the old to the new members. The plan was to reduce direct payments for 3\% starting from 2004 (Prokopijević, 2009) and that the saved funds qualify for the rural development (besides decreasing of the guaranteed prices). The funds are directed to the villages in order to motivate the farmers in terms of performing of non-agricultural activities. This was particularly true in the improvement of environmental standards in order to reduce the pollution of the environment and the food production.

The entry of the 10 new EU countries has nearly doubled agricultural labor and arable land, which has made a serious pressure on the CAP (van Berkel and Verburg, 2011). During the pre-accession negotiations, agriculture was comprised mostly of directives and other legal acts. For new members, EU has provided gradually joining to the system of direct payments, which covered the period 2004-2013, where 2013. presents the final year of full implementation to the system.

All these CAP reforms have caused determination of the agricultural prices by the free market. This means that the CAP is no longer deals with resource allocation and market stabilization. Now he has two new roles:

- The CAP has become a liberal welfare regime (according to Esping-Andersen typology), which means that the public programs are funded through taxation and that the social benefits are reserved for low income farmers;

- With more attention on environmental issues, rural development and food security, the CAP aims to become a general public policy in interest of all nations within EU.

\section{Europe 2020}

Treaty of Lisbon or Reform Treaty was signed by the EU members on $13^{\text {th }}$ December 2007 and entered into force on $1^{\text {st }}$ December 2009. In this process, the former Treaty of

9 The current figure is $41 \%$ of EU budget, which is success, since the beginning of the European integration was even $74 \%$.

10 The largest territorially expansion of the EU. „Big Bang“ policy has covered the entry of Estonia, Latvia, Lithuania, Malta, Cyprus, Poland, Czech Republic, Slovakia, Hungary and Slovenia.

11 First 15 EU member states.

EP 2014 (61) 3 (759-770) 
Rome was renamed to Treaty on the Functioning of the European Union. The most profited institution with Treaty of Lisbon are European Parliament (extension of jurisdiction in decision making process) and European Council (assume the certain responsibilities of the Commission, institute of President, etc.), and one of the main novelty is that the draft version of Constitution envisaged abolition of previous treaties, while Lisbon these old treaties just changing, not repealing. Treaty on the Functioning of the EU, compared to the previous contracts, exerts less formal changes in terms of agriculture: Articles 32-38 according to the new Treaty are Articles 38-44 and introduce the concept of "international market" instead of common market (Miščević and Gavrilović, 2010). Additionally, the Treaty did not separate a common policy of the CAP in terms of fishing, neither the major shift in terms of adjusting the goals and founding principles of the CAP to the new citizens demands in terms of agricultural activities, especially in following: sustainable development, product quality, public health and customer protection, rural development and consolidation of multifunctional agriculture all over the EU and finally, contribution of agriculture in climate changing. Although at first seems superficial, the Treaty of Lisbon will certainly cause a major changes within the CAP, especially in terms of legislation, executive and financial levels (European Commission, 2012a).

The agriculture is certainly an integral part of the European economy and society. In terms of indirect effects, each stumble of European farmer is reflected on the employment scale in economic sector, especially in the agro-food chain which is related on the primary agriculture production. Sectors like a rural tourism, transport, etc. would also be affected by these deviations. According to this report, it is necessary to reform the CAP and to continue in direction of bigger market competitiveness and better fund utilization received from tax payers.

The three main objectives of the CAP within the project "Europe 2020" is:

\section{Sustainable food production}

The main role of agriculture is food supplying. For the highly competitive food industry, it is necessary to have a strong agricultural sector which will provide the following:

- Contribution to the farmer income and minimal variation of the revenue, noting that the volatility of the price, income, natural risks, and the level of profitability in agriculture, in average, is poorer than the rest of the economy;

- Production compensation in the areas that is naturally limited, since in such regions the risk of leaving the country is on the higher level than usual.

\section{Sustainable management of national resources and actions on climate change}

- To foster the "green growth" through innovation which requires adoption of new technologies, new products development, changes to existing manufacturing processes and support new patterns of demand, particularly in the context of the bio economics emergence (Rametsteiner et al., 2011); 
- To reduce the effects caused by climate change and adopt the actions that are necessary to make agriculture adequately respond to these changes.

\section{Balanced territorial development}

- Rural employment supports the social structure maintenance of rural areas;

- Rural economy improvement and promotion of diversification is to enable the local stakeholders to fully exploit the potential and to optimize the use of limited local resources (European Commission 2012b).

Table 1. Agricultural income in the EU (period 2014-2023)

\begin{tabular}{|l|c|c|c|c|c|c|c|c|c|c|}
\hline $\begin{array}{c}\text { Group/ } \\
\text { Year }\end{array}$ & $\mathbf{2 0 1 4}$ & $\mathbf{2 0 1 5}$ & $\mathbf{2 0 1 6}$ & $\mathbf{2 0 1 7}$ & $\mathbf{2 0 1 8}$ & $\mathbf{2 0 1 9}$ & $\mathbf{2 0 2 0}$ & $\mathbf{2 0 2 1}$ & $\mathbf{2 0 2 2}$ & $\mathbf{2 0 2 3}$ \\
\hline \multicolumn{10}{|c|}{ Factor income in nominal terms } \\
\hline EU28 & 110,6 & 115,1 & 115,1 & 114,3 & 116,1 & 117,8 & 116,0 & 115,2 & 115,5 & 114,7 \\
\hline EU15 & 105,8 & 109,7 & 109,7 & 108,7 & 110,1 & 111,6 & 109,9 & 109,0 & 109,3 & 108,5 \\
\hline EU-N13 & 140,6 & 148,5 & 148,2 & 148,9 & 152,9 & 155,6 & 154,1 & 153,8 & 153,9 & 153,2 \\
\hline \multicolumn{10}{|c|}{ Factor income in real terms } \\
\hline EU28 & 96,7 & 98,9 & 97,1 & 94,6 & 94,3 & 93,9 & 90,8 & 88,5 & 87,1 & 84,9 \\
\hline EU15 & 94,9 & 96,9 & 95,2 & 92,6 & 92,1 & 91,7 & 88,6 & 86,3 & 85,0 & 82,8 \\
\hline EU-N13 & 107,5 & 111,4 & 108,7 & 106,9 & 107,4 & 107,1 & 103,9 & 101,6 & 99,6 & 97,1 \\
\hline \multicolumn{10}{|c|}{ Labor input } \\
\hline EU28 & 76,5 & 74,1 & 71,8 & 69,5 & 67,4 & 65,3 & 63,3 & 61,4 & 59,5 & 57,7 \\
\hline EU15 & 84,0 & 82,4 & 80,8 & 79,3 & 77,7 & 76,2 & 74,7 & 73,3 & 71,9 & 70,5 \\
\hline EU-N13 & 69,9 & 66,9 & 63,9 & 61,1 & 58,5 & 55,9 & 53,5 & 51,1 & 48,9 & 46,7 \\
\hline \multicolumn{10}{|c|}{ Agricultural income in real terms per labor unit } \\
\hline EU28 & 126,3 & 133,4 & 135,1 & 135,8 & 139,8 & 143,5 & 143,2 & 143,9 & 146,0 & 146,8 \\
\hline EU15 & 112,9 & 117,5 & 117,7 & 116,7 & 118,5 & 120,3 & 118,5 & 117,7 & 118,2 & 117,5 \\
\hline EU-N13 & 153,3 & 166,1 & 169,5 & 174,3 & 183,2 & 190,9 & 193,7 & 198 & 203,1 & 207,1 \\
\hline
\end{tabular}

Source: European Commission, 2013a.

According to period 2014-2023, the agricultural income per labor unit is projected to be $46.8 \%$ above the period $2003-2007$, which is an increase of $1,8 \%$ per year (Table 1). The main reason in this positive trend, we can find in continuous decrease of the labor force in agriculture: from 76,5 to 57,7 (European Commission, 2013a). Inside of EU28, EU15 is expected to increase by $17,5 \%$ by 2023 compared to the 2003-2007 average, whereas in the EU-N13 it more than doubled. As a result, the gap between the absolute levels of agricultural income per worker in the EU15 and the EU-N13 will narrow further but still with appreciably difference. The EU-N13 will continue with adjustments of agricultural workforce and that policy will consequent in the income development deference regarding to EU15.

Real agricultural income per labor unit in the EU-28 is not expected to follow a steady pattern. In 2014 producer prices are expected to decrease, especially for crops $(-11.2 \%)$. The fall in the value of production is offset by a sharper decrease of the intermediate costs, which are driven by the lower expenditure on feed, energy and fertilizers, and result in an increase in nominal income. In 2015, the value of production is expected to develop steadily, while intermediate EP 2014 (61) 3 (759-770) 
costs would continue to decline, causing income to rise in both nominal and real terms. After a period of stable nominal total factor income, income should rise again in 2018 and 2019 due to increasing prices for most commodities (especially for pork). In the last four years of the projection period volumes produced increase slightly for all products. Producer prices raise moderate for crops and meat whereas producer prices for milk are expected to decrease. Given the assumed increase in energy and fertilizer prices, intermediate costs will continue to rise, and together with the rising fixed capital consumption, outweigh the increase in the value of production so that total factor income in nominal terms decreases between 2019 and 2023 (European Commission, 2013a).

According to EU Regulation from 17 ${ }^{\text {th }}$ December 2013 (European Parliament, European Council, 2013b) the new rules for direct payments will be established for all Members States. In this paper, we single out the 3 last one - Romania, Bulgaria and Croatia.

Table 2. Direct payments in 2015. for Bulgaria and Romania

\begin{tabular}{|l|c|c|}
\hline \multicolumn{1}{|c|}{ Element } & Bulgaria & Romania \\
\hline $\begin{array}{l}\text { Amounts for applying point (a) of Article } \\
\text { 10(1) and for calculating the national ceilings } \\
\text { for payments referred to in Article 16 in } \\
\text { 2015: }\end{array}$ & EUR 790.909.000,00 & EUR 1.783.426.000,00 \\
\hline $\begin{array}{l}\text { Total amount of complementary national } \\
\text { direct payments to the basic payment scheme } \\
\text { referred to in Article 18(1) in 2015: }\end{array}$ & EUR 69.657.000,00 & EUR 153.536.000,00 \\
\hline $\begin{array}{l}\text { Total amount of complementary national } \\
\text { direct payments to the crop-specific payment } \\
\text { for cotton referred to in Article 18(2) in 2015 }\end{array}$ & EUR 258.952,00 & \\
\hline
\end{tabular}

Source: European Parliament, European Council, 2013b.

In Bulgaria and Romania, for the year 2015, the amount claimed or due to be granted as referred to in Regulation (EU) No 1307/2013 shall be calculated on the basis of the relevant amount set out in the table 2. Beside direct payments from the EU budget, Bulgaria and Romania can use national direct payments as additional force under the basic payment scheme and crop specific payment for cotton. On this way they can boost the national agriculture and to catch up the States from the EU15. The total amounts of those payments shell not exceed programmed amounts which are set out in the table 2 . All granted payments need to be in accordance of objective criteria in order to provide equal treatments of the farmers, and to avoid unfair competition and distortion on the market (European Parliament, European Council, 2013). In case of Croatia, European Commission will grant the national direct payments which will be suitable for necessary developments within the CAP under the same conditions like for the Bulgaria and Romania - equal treatment of farmers and avoiding of potential distortion on the market. The Croatia will have one more additional term - to submit the report on the measures for the implementation of the complementary national direct payments (number of beneficiaries, hectares which are covered with national direct payments, covered livestock, etc.). On this way, the EU will try to give a space for Croatia supervised development. This is very important if we consider current state of the Croatian 
agriculture and the policy of the liberal market inside the EU. Also, almost the only instrument which Croatia used successfully is direct payments (Vapa Tankosić and Stojsavljević, 2014). Direct payments in Croatia, shall be introduced in accordance with the following schedule of increments expressed as a percentage of the corresponding) level of the direct payments as applied from 2022 (Table 3).

Table 3. Direct payments in Croatia (available 373 mil EUR)

\begin{tabular}{|c|c|c|c|c|c|c|c|c|}
\hline $\mathbf{2 0 1 4}$ & $\mathbf{2 0 1 5}$ & $\mathbf{2 0 1 6}$ & $\mathbf{2 0 1 7}$ & $\mathbf{2 0 1 8}$ & $\mathbf{2 0 1 9}$ & $\mathbf{2 0 2 0}$ & $\mathbf{2 0 2 1}$ & $\mathbf{2 0 2 2}$ \\
\hline $30 \%$ & $35 \%$ & $40 \%$ & $50 \%$ & $60 \%$ & $70 \%$ & $80 \%$ & $90 \%$ & $100 \%$ \\
\hline- & 242.450 & 223.800 & 186.500 & 149.200 & 111.900 & 74.600 & 37.300 & - \\
\hline
\end{tabular}

Source: European Parliament, European Council, 2013b.

\section{Conclusion}

The CAP has been almost 50 years one of the most expensive EU policies. It talks about its importance, not only for farmers and citizens of the Union, but also for the development of EU integration in general. The fact is that in 1962 participation of the population in agriculture was much higher than today, and at that moment the developing of European idea needed to be supported by European farmers. It was completed through the CAP, which at that time was more than $70 \%$ of the EEC budget. This policy was suitable for the France because of the large agricultural sector and because of the finance centralization via EEC budget which was mainly stuffed with the money from Germany and Netherlands. Germany also finds its benefit: after turbulent period it managed to become a part of an international organization and on the other side, it opens the bigger market for German industrial products. The CAP as it is still causes a lot of controversy within the EU institutions. On one side we have lobby groups that are committed to maintaining a highly protected policy in agriculture, and the other liberal economists who cannot accept such concept of protectionism. Although the current CAP is quite expensive for the EU budget, it can be said that it has experienced some decline in dominance as a primary policy in the EU. The facts that confirm this claim are that the CAP at the beginning of European integration participates with $73 \%$ of the EEC budget, and the budget projections for 2014 provide "only" 33\%. The CAP itself has several drawbacks: spoiled farmers (read land owners) because of the huge protectionism, the CAP usefulness for all EU citizens are still under the question, there is major price disruptions, huge surpluses, unfairness in value allocation (large farmers get richer - small ones get poorer), distortion on global market, etc. The CAP drastically protects the farmers through subsidies, guaranteed prices, etc. and on that way favors the domestic producers according to foreign farmers. The results of such guarantees are huge surpluses, which have to be placed somewhere and the selection of the most fall on the African countries, Jamaica and similar. Such policy on the economically divested countries affect the breakdowns of the companies (who employing the 1.000 peoples) and households, which implies in increasing of unemployment. The question is what would happen if, within the CAP, the protectionism doesn't exist? Or if the EU cuts the benefits on much lower level? It is clear that European countries have ideal conditions for agriculture, such as climate conditions and arable land quality. But without such favoritism 
which they have today, their competitiveness will be highly questionable, primarily because of the high value products and expensive labor power. The second question is what is the real importance of the CAP in the general population of the EU? On this question the agricultural lobbyists have to provide arguments and extensive explanation. However, the "urban voters" mostly pay for this policy because they want quality and price available products. Presumably, the cheaper food will come when the EU borders become more opened for non-EU products, and when EU lowered the tariffs in order to increase competitiveness. Also, the EU needs to become an institution that establishes the rules without favoritism of the domicile producers. On that way, the people who finance the CAP will be winner - citizens and consumers.

\section{References}

1. European Commission (2011): Common Agricultural Policy towards Europe 2020 Assessment of Alternative Policy Options, available at: ec.europa.eu/agriculture/ policy-perspectives/impact-assessment/cap-towards-2020/report/full-text_en.pdf

2. European Commission (Agriculture and Rural Development), (2012a): The Common Agricultural Policy - A partnership between Europe and Farmers, Publication Office of the European Union, Luxembourg.

3. European Commission (2012b): Communication From The Commission To The European Parliament, The European Council, The Council, The European Central Bank, The European Economic And Social Committee The Committee Of The Regions And The European Investment Bank - Action for Stability, Growth and Jobs, Brussels, 30.05.2012. COM(2012), 299 final, available at: http://eurlex.europa. eu/legalcontent/EN/TXT/PDF/?uri=CELEX:52012DC0299\&from=EN

4. European Commission (Agricultural and Rural Development), (2013a): Prospects for Agricultural Markets and Income in the EU 2013-2023, available at: http:// ec.europa.eu/agriculture/markets-and-prices/medium-term outlook/2013/fullrep_en.pdf

5. European Commission (Agricultural and Rural Development), (2013b): Regulation (EU) No 1307/2013 of the European Parliament and of the Council of $17^{\text {th }}$ December 2013 „Establishing rules for direct payments to farmers under support schemes within the framework“.

6. Hiks, S. (2007): Politički Sistem Evropske Unije, II izdanje, Službeni glasnik, Beograd.

7. Knizkel, K., Brunori, G., Rand, S., Proost, J. (2009): Towards a Better Conceptual Framework for Innovation Processes in Agriculture and Rural Development: From Linear Models to Systemic Approaches, Journal of Agricultural Education and Extension, Vol. 15, no. 2, pp. 131-146.

8. Marković, I., Marković, M. (2014): Agricultural Protectionism of the European Union in the Conditions of International Trade Liberalization, Economics of Agriculture, Vol. 61, no. 2, IAE Belgrade, pp. 423-440.

9. Miščević, T., Dragojlović, N. (2010): Vodič kroz EU politike - Poljoprivreda, Evropski pokret Srbija, Beograd. 
10.Miščević, T., Gavrilović, S. (2010): Ugovor iz Lisabona - sigurna luka ili početak novog putovanja?, Službeni Glasnik: Fondacija Fridrih Erbert, Beograd.

11. Pezaros, P. (1999): The Agenda 2000. CAP reform agreement in the light of the future EU enlargement, Working Paper 99/W/02, European Institute of Public Administration - EIPA, Maastricht.

12.Prokopijević, M. (2009): Evropska unija - uvod, II dopunjeno izdanje, Službeni Glasnik, Beograd.

13.Rametsteiner, E., Puelzi, H., Alkan Olsson, J., Frederiksen P. (2011): Sustainability indicator development - Science or political negotiation? Elsevier Ltd., Ecological Indicators, Vol. 11, no. 1, pp. 61-70.

14. Van Berkel, B. D., Verburg, H. P. (2011): Sensitizing rural policy: Assessing spatial variation in rural development options for Europe, Elsevier LTD., Land use policy, Vol. 28, no., pp. 447-459.

15.Vapa Tankosić, J., Stojsavljević, M. (2014): EU Common Agricultural Policy and Pre-Accession Assistance Measures for Rural Development, Economics of Agriculture, Vol. 61, no. 1, IAE, Belgrade, pp. 195-201.

16.Zobbe, H. (2001): The Economic and Historical Foundation of the Common Agricultural Policy in Europe, $4^{\text {th }}$ European Historical Economics Society Conference, Oxford-United Kingdom: Merton College. 


\title{
ZAJEDNIČKA POLJOPRIVREDNA POLITIKA KROZ REFORME KA EVROPI 2020
}

\author{
Goran Puzićc ${ }^{12}$, Aleksandar Klevernic ${ }^{13}$, Zoran Pavlović ${ }^{14}$
}

Rezime

U startu evropskog integracionog procesa, iako je akcenat bio na Evropskoj zajednici za ugalj i čelik, poznata je informacija da je u ovom procesu poljoprivreda imala specifičan tretman. Ne retko, poljoprivredni sektor bio je i opredeljujući faktor dinamike i intenziteta integracionih procesa u celini. Ta uloga ni sada ne izostaje, ali u dosta izmenjenim uslovima $i$ strategijom koja sadrži nove razvojne ciljeve i mehanizme. Zajednička poljoprivredna politika je duže od 50 godina jedna od nasjkupljih i najintrigantnijih politika EU, kako za poljoprivrednike i građane, tako i za EU integracije uopšte. Ona, pored Regionalne politike, predstavlja ključnu politiku EU i mnogi aspekti EU politika se prelamaju na ovoj temi. Cilj ovog istraživanja je presek dosadašnjih reformi Zajedničke poljoprivredne politike do nove Agende „Evropa 2020“, kao i njen uticaj na dohodak i politiku direktnih plaćanja u poljoprivredi Bugarske, Rumunije i Hrvatske. U toku istraživanja ovog rada koristili smo metode političko-pravno-ekonomske analize u strukturno-dinamičkom kontekstu političkog sistema EU pre i nakon usvajanja Lisabonskog ugovora.

Ključne reči: Zajednička poljoprivredna politika, EU, Reforme ZPP, Evropa 2020.

12 Prof. dr Goran Puzić, Vanredni profesor, Megatrend Univerzitet, Fakultet za pravo, javnu administraciju i bezbednost, Bulevar umetnosti 29, 11070 Novi Beograd, Srbija, Telefon: +38165 20819 77, E-mail: gpuzic@megatrend.edu.rs

13 Aleksandar Klevernić, M.Sc., Vulcascot d.o.o., Vladimira Nazora BB, 22400 Ruma, Srbija, Telefon: +3816525272 79, E-mail: a.klevernic@vulcascot.rs

14 Prof. dr Zoran Pavlović, Vanredni profesor, Pravni fakultet za privredu i pravosuđe, Univerzitet privredna akademija, Geri Karolja 1, 21000 Novi Sad, Srbija, Telefon: +381 65 8677 949, E-mail: zoran.pav@hotmail.com 